\title{
Mao Zedong'un Kült Liderlik Propagandasında Kullanılan Posterlerin Göstergebilimsel Analizi
}

\section{The Semiotics Analysis of Posters Used in Mao Zedong's Cult Leadership Propaganda}

\section{Caner Çakı ${ }^{1}$}

Başvuru Tarihi: 10.04.2019

Kabul Tarihi: 01.05.2019

Öz

Mao Zedong, 1949 yılında Çin'de milliyetçi lider Çan Kay Şek'i iç savaşta yenerek Komünizm ideolojisi altında Çin Halk Cumhuriyeti kurmuştu. Mao'nun ülke yönetimini ele geçirmesinden sonra Çin propagandası Mao'yu ülke genelinde kült lider olarak inşa etmeye başlamıştı. Böylece Mao'nun kurduğu rejiminin ülkede sağlam temellere oturması amaçlanmıştı. Mao'nun kült liderlik propagandasında dönemin kitle iletişim araçları yoğun bir şekilde kullanılmıştı. Dönemin en etkili kitle iletişim araçlarından biri olan posterlerden de Mao'nun kült liderlik propagandasında etkin bir şekilde yararlanılmıştı. Bu çalışmada Çin propagandası tarafından Mao'nun kült liderlik inşasında posterleri nasıl ve ne yönde kullandiğı ortaya çıkarılmaya çalışılmıştır. Bu amaçla çalışma kapsamında amaçlı örneklem metodu kullanılarak belirlenen 8 propaganda posteri, nitel araştırma yöntemleri içerisinde yer alan göstergebilimsel analiz metodu kullanılarak incelenmiştir. Çalışmada belirlenen Çin propagandasına ait posterler Fransız dilbilimci Roland Barthes'ın göstergebilim kavramları ışı̆̆ında analiz edilmiştir. Çalışma elde edilen bulgular ışı̆̆ında, Çin propaganda posterlerinde Mao'nun Çin Halk Cumhuriyeti'nin ekonomik refahının artmasında, sosyal adaletin sağlanması ve iç huzurun sağlanmasında temel aktör olarak inşa edildiği sonucuna ulaşılmıştır.

Anahtar Kelimeler: Kült Liderlik, Propaganda, Mao, Poster, Göstergebilim

\begin{abstract}
Mao Zedong founded the People's Republic of China under the Communism ideology, defeating the nationalist leader Chiang Kai-Shek in the civil war in 1949. After Mao came to power in the country, the Chinese propaganda began to build Mao as a cult leader throughout the country. Thus, Mao's regime was intended to ensure its legitimacy. In Mao's cult leadership propaganda, the mass media tools of that period were used extensively. The posters, one of the most influential mass media tools in that time, were effectively used in Mao's cult leadership propaganda. In this
\end{abstract}

${ }^{1}$ İnönü Üniversitesi İletişim Fakültesi, caner.caki@inonu.edu.tr, ORCID: 0000-0001-9091-5957 
study, it was tried to find out how and in what way the posters were used in Mao's cult leadership construction by Chinese propaganda. For this purpose, 8 propaganda posters, which were determined by using purposive sampling method, were examined by using semiotic analysis method in qualitative research methods. In the study, Chinese propaganda posters were analyzed in the context of semiotics concepts of the French linguist Roland Barthes. In light of the findings obtained, it was concluded that Mao was constructed as the main actor in increasing the economic prosperity, ensuring social justice and ensuring inner peace of the People's Republic of China in Chinese propaganda posters.

Keywords: Cult Leadership, Propaganda, Mao, Poster, Semiotics

\section{Giriş}

20. yüzyılda Komünizm, Nazizm ve Faşizm ideolojileri altında yönetilen ülkelerde propaganda yoluyla Vladimir Lenin, Adolf Hitler, Benito Mussolini gibi devlet adamları kitleler karşında kült liderler olarak inşa edilmeye çalı̧sılmıştır. Kült liderlik propagandası özellikle Komünizm ideolojisi altında yönetilen ülkelerde sıklıkla görülmektedir. Bu ülkelerin başında da Çin Halk Cumhuriyeti gelmektedir. Çin Halk Cumhuriyeti'nin kuruluşundan itibaren ülkede Çin Komünist Partisi lideri Mao Zedong'un kült liderlik propagandası hakim olmaktadır. Komünizm ideolojisinde kitlelere ilk kült lider olarak sunulan kişi Lenin olmuştu (Tumarkin, 1997, s.3). Mao da, Çin'de Lenin kültüne benzer bir şekilde kült lider olarak inşa edilmişti. Mao'nun portreleri ülkenin dört bir yanına asılmakta, resimleri paraları ve posta pullarını süslemekte, devrimleri ders kitaplarında yer almakta, heykelleri şehirlerin en görkemli alanlarına konulmaktadır. Mao'nun Çin kamuoyunda kült lider olarak inşa edilmesinde kitle iletişim araçları etkili bir şekilde kullanılmıştır. Özellikle Mao'nun iktidarı döneminde (19491976) ülkedeki en etkili kitle iletişim araçlarından biri olan posterlerden kült liderlik propagandasında etkili bir şekilde yararlanılmışır. Mao'nun kült liderlik propagandası 1976 yllında ölümünden sonra da sürmüş, Çin halkının Mao'nun öğretileri doğrultusunda yaşamalarını sürdürmeleri telkin edilmeye devam etmiştir. Mao kültü, günümüzde Çin Halk Cumhuriyeti'nde hala etkisini sürdürmektedir.

Türkiye'de son yıllarda kült liderlik propagandası üzerine alanda önemli akademik çalışmaların yapıldığı görülmektedir. Bunlar içerisinde; Çakı (2018a), "Adolf Hitler'in Kült Lider İnşasında Kullanılan Propaganda Posterlerinin Göstergebilimsel Analizi" adlı çalı̧̧mada eski Alman Devlet Başkanı Adolf Hitler'in kült liderlik propagandasında posterler üzerinden ne şekilde sunulduğunu analiz etmiştir. Çalışmada elde edilen bulgularda, posterlerde Hitler olmadan Almanya'nın büyük bir devlet olamayacağı üzerinde durulduğu ve bu nedenle Hitler'in emirlerinin Alman kamuoyunda tartışmasız kabul edilmesi için çalışıldığı ortaya konulmuştur. Çakı (2018b), "Komünizm İdeolojisinde Kült Lider Olgusu: Berlin'in Düşüşü Propaganda Filmi'nin Alımlama Analizi" adlı çalışmada eski Sovyet Devlet Başkanı Joseph Stalin'in kült liderlik propagandasında kullanılan Berlin'in Düşüşü filmi üzerine alımlama analizi yapmıştır. Çalı̧̧ma sonucunda Sovyet lider Stalin'in kült liderlik propagandasında genel olarak gri ve kara propagandadan yararlanıldığı sonucuna ulaşılmıştır. Gazi vd. (2018a), "İkinci Dünya Savaşı'nda 
Sovyet Kült Lider Propagandasında Vladimir Lenin ve Joseph Stalin'in Sunumu" adlı çalışmada Sovyet liderleri Lenin ve Stalin'in kült liderlik propagandasındaki sunumları posterler üzerinden incelemiştir. Çalışmada Lenin'in kült liderlik propagandası üzerinden Stalin'in kült lider olarak inşa edilmeye çalışıldığı sonucuna varılmıştır. Karaca (2018), "İtalyan Propagandasında Kült Lider Olgusu: Il Duce Benito Mussolini" adlı çalışmada eski İtalyan başbakanı Benito Mussoli'nin propaganda posterlerinde kült lider olarak nasıl inşa edildiği ele almıştır. Çalışma sonucunda İtalyan propaganda posterlerinde İtalyan halkının Mussolini'ye kayıtsız şartsız bağlı olduğu mitinin inşa edildiği, aynı zamanda Mussolini liderliğinde İtalya'nın Roma İmparatorluğu'ndaki gibi büyük bir imparatorluk olacağı algısının meydana getirildiği ortaya çıkarılmıştır. Çakı ve Gülada (2018) "Duvar Resimleri Üzerinden Kült Liderlik Propagandası: Irak Devlet Başkanı Saddam Hüsseyin Üzerine İnceleme" adlı çalışmada da eski Irak devlet başkanı Saddam Hüseyin'in kült liderlik inşasında duvar resimlerinin propaganda amaçlı nasıl kullanıldığını analiz etmiştir. Elde edilen bulgularda, posterlerde Irak'ın geçmişteki zaferlerinin Saddam ile tekrar kazanılacağına yönelik bir algının inşa edildiği ve Saddam'ın ulusal kahraman olarak sunulduğu sonucuna ulaşmıştır.

Türkiye'de ulusal akademik çalışmalar içerisinde yapılan literatür taraması sonucunda, Çin örneklemi özelinde kült liderlik propagandası ile ilgili herhangi bir çalışmaya rastlanılamamıştır. Çalışma kapsamında Mao'nun kült liderlik inşasında propaganda disiplininden ne şekilde yararlanıldığı açıklanmaya çalışılmıştır.

\section{Kült Liderlik Propagandasına Genel Bakış}

Propaganda, bir ideal, düşünce, fikir veya ideolojiyi kaynaktan alıcıya tek yönlü bir iletişim çerçevesinde kitle iletişim araçlarından yararlanarak, kitlelere kabul ettirmeyi ve beraberinde kitleleri harekete geçirmeyi amaçlayan ikna odaklı bir iletişim biçimidir (Çakı, 2018c, s.16). Propaganda kavramı diğer bir tanımıyla, kitlelerin fikirlerini manipüle etme, algılarını şekillendirme ve propagandacı tarafından arzulanan bir niyet üzerine tepki oluşturmayı amaçlayan kasıtlı ve sistematik bir girişimi ifade etmektedir (Jowett ve O'donnell, 2014, s.7). 20. yüzyılda farklı ideolojik söylemler dünyada etkili olmaya başlamıştı (Zorlu vd., 2017, s.69). Bu süreçte siyasal propaganda kavramı ideolojilerin dünyaya hakim olmaya başladığı dönemde ön plana çıkmıştı (Çakı, 2018d, s. 79). Nitekim Komünizm, Faşizm ve Nazizm gibi farklı ideolojilere sahip partilerin iktidarı yakalamalarında propaganda önemli bir rol oynamıştır (Domenach, 2003, s.15). Çünkü propaganda kitlelerin belirli bir ideolojiyi kabul etmesinde ve o ideolojinin öğretileri doğrultusunda hareket etmesinde önemli bir araç olarak kullanılabilmektedir (Stanley, 2018, s.27-28). Diğer yandan propagandanın demokratik olmayan ülkelerde daha etkili olduğu söylenebilinmektedir. Özellikle tek partili sistemlerin olduğu ülkelerde propaganda, kitlelerin kontrol altında tutulmasında önemli bir araç olmaktadır (Aziz, 2007, s.15). Propagandanın tarihi insanlık tarihi kadar eskidir. Buna karşın 20. yüzyılda propaganda disiplini tarihte hiç olmadığı kadar etkili bir şekilde kullanılmıştır. Yine bu yüzyılda kült liderlik propagandası da önem kazanmaya başlamıştır.

Kült olmak bir kavramın, nesnenin veya bir kişinin kitleler nezdinde popülerlik kazanması ve belirli bir dönem onun hakkında konuşulmasını ifade etmektedir. Kült haline getirilen kavram üzerinde kitlelerin hayranlığının veya sevgi gösterisinin ön plana çıkarılması amaçlanmaktadır. 
Kült kavramındaki hayranlık kimi zaman tapınmaya kadar ileri gidebilmektedir. Liderlik kültü veya diğer bir kullanımıyla kült liderlik ise bir liderin veya devlet başkanının kahraman veya efsanevi bir kişilik olarak kitleler nezdinde inşa edilmesini ifade etmektedir. Kült liderlik ya da kişilik kültü ise siyasi bir liderin propaganda yoluyla övülmesi ve kitlelere efsanevi bir kahraman olarak sunulmasıdır. Kült liderler, kitlelerin hayatlarında tamamen yönlendirici bir etkiye sahiptir. Kült liderlerin hâkim olduğu yerlerde bireyler görüşlerini ortaya koyamazlar, kendi başlarına karar alamazlar (Schwartz, 1983, s.171). Kült liderlik propagandası da liderin, kült lider olarak inşa edilmesi amacıyla yapılan propaganda faaliyetlerini ifade etmektedir. Kült liderlik propagandası okullardaki müfredattan, kamu mimarisine kadar oldukça geniş bir olguyu temsil etmektedir (Gundle vd., 2015, s.2). Kült liderlik propagandasında lidere ait resim ve fotoğrafların sürekli olarak ön plana çıkarılması amaçlanmaktadır. Bu nedenle lidere ait resim ve fotoğraflar, resmi dairelerde, paralarda, pullarda, posterlerde, afişlerde ve kartpostallarda sık sık kullanılmaktadır. Benzer şekilde şehirlerin en görkemli meydanlarında liderlerin farklı açılardan heykellerine yer verilmektedir. Bu şekilde kitlelerin sürekli olarak liderler ile temas halinde olması istenmektedir. Diğer yandan okullardan hastanelere, fabrikalardan hapishanelere kadar pek çok farklı resmi kurumun duvarına liderlerin slogan haline getirilen sözleri yazılmaktadır. Liderin hayatı, iktidara gelişi, kazandığı zaferler ve devrimler ders kitaplarına konu edilmekte, böylece daha çocukluk dönemlerinde kitlelerin kült lideri tanımaları ve ona hayranlık beslemeleri amaçlanmaktadır.

Kült liderlik propagandasında, lider yaşayan efsanevi bir kişilik olarak kitlelere sunulmaktadır. İktidardaki egemen güçler tarafından yapılan propagandada kült liderin, hayatını yalnızca halkına adadığı, kişisel zevklerden uzak, halkının mutluluğu için sürekli olarak çalıştığı algısının oluşturulması amaçlanmaktadır (Gill, 1980, s.167). Bu şekilde kitlelere; kült liderlerin halkı için en doğru karar alan kişiler olduğu, diğer insanların kült liderler kadar doğru karar veremeyeceği ve bu yüzden kitlelerin kült liderin kararlarına doğrudan uymaları gerektiği aktarılmaktadır. Kült lider olarak inşa edilen liderin aldığı kararların kitleler tarafından sorgulanması, eleştirilmesi ve hatta yorumlanmasının bile önüne geçilmesi amaçlanmaktadır. Bu yolla iktidarın meşruiyetinin güçlendirilmesi hedeflenmektedir.

Kült lider olarak inşa edilen devlet başkanları, kendi rejimlerine ait öğretileri veya ideolojik söylemleri topluma dikte ettirmede önemli bir avantaj elde edebilmektedir. Bu açıdan kült liderlik propagandasının kitleler üzerinde kontrol kurulmasında önemli bir araç olduğu söylenebilmektedir (Goldberg, 1997, s.72). Kült liderlik, yalnızca liderin değil mevcut rejimin de meşruiyetinin sağlanması amacıyla kullanılabilmektedir. Çünkü liderin savunduğu ideolojinin ülke yönetiminde uygulanabilecek olan en doğru idare biçimi olduğu düşüncesi kitlelere arasında hakim olmaktadır. Böylece kitleler, ideolojinin kendilerine telkin ettiği fikirleri benimseyerek hareket etmekte ve liderlerine duydukları güven ve sadakati ideolojiye yönelik de gösterebilmektedir (Koch, 2016, s.337-338). Kült liderlik kimi zaman ülke içerisinde bağımsız şeklide oluşabilirken, kimi zaman da başka ülkelerin etkisinde kalınabilinmektedir. Örneğin Kuzey Kore lideri Kim İl-sung'un kült liderliği iktidarının ilk dönemlerinde Stalin'in etkisi altında kalmış, buna karşın ilerleyen dönemde Kim İl-sung Kuzey Kore'de tamamen bağımsız kendi kült liderliğini inşa etmiştir (Tertitskiy, 2015, s.209). Benzer şekilde Çin Halk Cumhuriyeti lideri Mao Zedong'un kült liderlik propagandası iktidarının ilk yıllarında Stalin'in 
etkisi altında kalmış, buna karşın ilerleyen süreçte Çin propagandası tarafından tamamen Mao'ya özgü "Mao kültü" inşa edilmeye çalışılmıştır. Mao kültünün inşası dünya tarihindeki en etkili kült liderlik propagandalarından birinin sonucu olarak meydana gelmiştir.

\section{Mao Zedong 'un Kült Liderlik Propagandası}

20. yüzyıldan kült liderlik propagandasının en sık kullanıldığı ülkelerin başında Sovyetler Birliği gelmiştir. Sovyetler Birliği'nde ilk kült liderlik propagandası, Sovyetler Birliği'nin kurucusu Vladimir Lenin'e yönelik yapılmıştır. Sovyetler Birliği, Lenin'den sonra yönetime gelen Joseph Stalin için de yoğun bir kült liderlik propagandasına girişmiştir. Stalin'in ölümünden sonra Sovyetler Birliği'nin başına geçen Nikita Kruşçev, Lenin kültünün devam etmesine izin vermiş, buna karşın Stalin'e yönelik uygulamış olduğu sert muhalefet nedeniyle Stalin kültünün ülke genelinde sürmesine izin vermemiştir. Böylece Lenin kültü Sovyetler Birliği'nin 1991 yllında yıkılmasına kadar kullanılan en etkili kült liderliği olmuştu. Günümüzde ise Rusya'da kült liderlik propagandasının doğrudan Vladimir Putin üzerine yoğunlaştı̆̆ görülmektedir (Sperling, 2016, s.13). Sovyetler Birliği'nde uygulanan kült liderlik propagandası Komünizm ideolojisi ile yönetilen diğer ülkeleri de etkisi altına almıştı. Bu ülkelerden biri de Çin Halk Cumhuriyeti olmuştur.

Mao'nun liderliğindeki Çinli komünistler, 1949 yllında milliyetçi lider Çan Kay Şek'i yenilgiye uğratmış ve 1 Ekim 1949 tarihinde Çin Halk Cumhuriyeti'nin kurulduğunu ilan etmişti. Çan Kay Şek liderliğindeki milliyetçiler de Çin'i terk ederek, Tayvan'da kendi devletlerini kurmuştu (Mcmahon, 2013, s.58-59). Mao, Çin'de yönetimi tamamen ele geçirmesine karşın, Tayvan'da bulunan Çan Kay Şek ile sürekli olarak rekabet içerisinde olmuştur. Diğer yandan Mao'nun iktidarı sırasında farklı kanallardan Mao'nun yönetimini eleştiren gruplar da olmuştu. Yaşanan tüm bu süreç Mao'nun dünyanın en kalabalık ülkesi olan Çin Halk Cumhuriyeti'ndeki meşruiyet sorununu da beraberinde getirmiş̧ti. Çin yönetimi, ülke genelinde Mao kültünü inşa ederek, Mao'nun baş rakibi Çan Kay Şek'in karşı propagandasını ortadan kaldırmayı amaçlamıştı. Nitekim Tayvan'da Çan Kay Şek'in yoğun şekilde kült liderlik propagandası yapılmakta, Çan Kan Şek'in şerefine sokaklara ismi verilmekte, hayatı ders kitaplarına konu edilmekte ve kimi zaman kendisine doğrudan insanüstü güç ve bilgelik atfedilmekteydi (Taylor, 2006, s.97). Mao, Çin İç Savaşı'nı kazanması nedeniyle Çin halkının kurtarıcısı olarak sunulmakta, liderliği altında ülkede uygulanan devrimlerin Çin'i müreffeh bir devlet yapacağı kitlelere aktarılmaktaydı.

Çin yönetimi tarafından, Mao'nun kült liderlik propagandasında görseller etkili bir şekilde kullanılmaktaydı. Ülkenin dört bir yanında Mao'ya ait portreler asılmaktaydı. Mao'nun portreleri diğer ülke devlet başkanlarının portrelerinin aksine yalnızca resmi dairelere değil, evlere, iş yerlerine asılmakta hatta araçların içine bile yerleştirilmekteydi. Böylece Çin halkının sürekli olarak Mao'yu hatırlamaları ve onun öğretilerini takip etmeleri telkin edilmekteydi. Mao'nun görselleri aynı zamanda Çin paralarını da süslemekteydi. Bu aşamada Mao'nun farklı bağlamlar içerisinde resim ve fotoğraflarına yer verilmekte, Mao'nun kültü farklı açllardan Çin halkına sunulmaktaydı (Lago, 1999, s.49). Çin propagandasının Mao kültü konusunda özenle durduğu bir diğer konu heykellerdi. Mao'nun heykelleri Çin'de kitlelerin en yoğun olduğu alanlara dikilmişti. Bunlardan en bilineni Çin Halk Cumhuriyeti'nin başkenti Pekin'deki 
Tiananmen Meydanı'nda bulunan Mao heykelidir. Mao'nun heykeli günümüzde hala bu meydanda bulunmaktadır (Priestland, 2017, s.15). Mao kültü çerçevesinde Mao'nun düşüncelerinin kitleler tarafından öğrenilebilmesi amacı ile de "Mao Zedong Düşüncesi" adlı eser oluşturulmuş ve Çin halkının bu kitabı okuması teşvik edilmişti (Priestland, 2017, s.282). Böylece Çin propagandası, kitlelerin Mao'yu daha iyi tanıyabilmelerini, yalnızca Mao'nun düşünceleri altında hareket etmelerini ve farklı liderlerin kitaplarındaki farklı ideolojik söylemlerin etkisi altında kalmamalarını amaçlanmıştı.

Mao, ülkesinde tüm yetkileri elinde bulunduran kimi zaman sert önlemler alabilen bir liderdi (Kissinger, 2010, s.705). Çin propagandası tarafından Mao kültünün inşa edilmesi ile Mao'nun ülkedeki otoritesi de daha da güç kazanmıştı. Mao'nun kült liderliği, Mao'nun Çin içerisinde Komünizm ideolojisinin öncüsü olmasının da bir temsili olarak yansıtılmaktaydı. Bu şekilde Çin halkının Sovyet liderlerinin etkisi altında kalması engellenerek Komünizm ideolojisinin doğrudan Çin içerisinde Mao ile özdeşleştirilmesi amaçlanmaktaydı. Diğer bir deyişle Mao ve onun düşüncesi, Marksizm-Leninizm'in soyut teorilerinin Çin gerçeklikleriyle başarılı bir şekilde birleştirilmesinde sembol olarak hizmet etmişti. Bu yolla Çin halkı üzerindeki kontrolün Sovyet liderleri Stalin veya Kruşçev kültü üzerinde yoğunlaşması engellenmekteydi (Leese, 2007, s.627). Mao, iktidara geldiği dönemde yoğun olarak Çin'in Sovyetler Birliği ile yakın ilişki içerisine girmesini sağlamıştı. Bu aşamada Stalin'in Mao'nun politikalarında önemli bir rolü bulunmaktayd.

Mao ve Stalin'in kült liderliği çok farklı koşullar altında oluşmuştu (Paltiel, 1983, s.49). Buna karşın kült liderlik kavramı, 1950'li yıllarda yaşanan Çin-Sovyet anlaşmazlığının evriminde önemli bir rol oynamıştı. Kruşçev'in, 1956'da parti kongresindeki konuşmasında Stalin'i resmi olarak kınanması, Stalin kültünün ülke genelinde telafisi zor bir şekilde zarar görmesine neden olmuştu. Kruşçev’in Stalin ile ilgili açıklamaları Komünist dünyasının bütününde şok dalgaları oluşturmuş ve etkileri günümüzde de hala belirgin şekilde hissedilmişti (Melnick, 1976, s.129). Sovyetler Birliği'nde Stalin kültünün zarar görmesi, Çin'de Mao kültünün daha etkili olabileceği bir ortamı şekillendirmişti. Bu süreçte Mao kültünün Stalin'in ölümden sonra yalnızca Çin sınırlarında değil, uluslararası komünist hareketin içerisinde de etkili olması teşvik edilmişti. Mao, Stalin'in ölümden sonra komünist hareketin en saygın ve deneyimli temsilcisi olarak ön plana çıarılmaya çalışılmış ve Mao'ya yönelik saygı ve hayranlığın duyulması amaçlanmıştı. Nitekim Mao, Kruşçev'in iktidarında Sovyetler Birliği'ni devrimin ruhundan uzaklaşmakla suçlamıştı. Mao'ya göre Çin gerçek devrim ülkesini temsil etmekteydi (Mcmahon, 2013, s.101102). Mao'nun Kruşçev karşıtı açıklamaları, iki dost ve müttefik ülke olan Çin ve Sovyetler Birliği'nin farklı çizgilere doğru yönelmesine yol açmıştı. Bu süreç beraberinde Mao kültünün tamamen bağımsız bir nitelik kazanmasını sağlamıştı.

Çin propagandası Mao'yu Çin halkı nezdinde yüceltmeyi ve bu yolla Mao'nun liderliğinin meşruluğunu sağlamayı amaçlamıştı (Leese, 2011, s.38; Landsberger, 1996, s.196). Böylece Çin Halk Cumhuriyeti tarihinde, Mao Zedong partiyi ve ülkeyi yönetmek için bir kişilik kültünü kullanan ilk ve potansiyel olarak son lider olmuştu (Luqiu, 2016, s.291). Çünkü Mao'dan sonra gelen Çinli liderler Mao kültünün korunmasını ve ülke genelinde sürmesini sağlamıștı. Bu nedenle Mao'nun kült liderlik propagandası, Mao'nun ölümünden sonra da devam etmişti. Bu 
şekilde Çin halkının Mao'ya olan sevgi ve saygısının sürdürülmesi hedeflenmişti. Diğger yandan Mao'nun öğretileri, Mao kültü ile birlikte ölümünden sonra da ülkede hakim olmaya devam etmişti (Barmé, 2016, s.14).

\section{Metodoloji}

\section{Çalışmanın Amacı}

Çin Halk Cumhuriyeti'nde Mao'nun kült liderlik propagandasında kullanılan posterlerde Mao'nun nasıl ve ne şekilde sunulduğunu ortaya koymak çalışmanın temel amacını oluşturmaktadır. Bu yolla Mao özelinde kült liderlik propagandasında posterlerin rolünün açıklanması amaçlanmıştır.

\section{Çalışmanın Önemi}

Çalışma;

- Çin Halk Cumhuriyeti dönemindeki propaganda faaliyetleri hakkında bilgi vermesi,

- Mao'nun kült liderlik propagandasında posterlerin rolünü ortaya çıarması,

- Mao'nun kült lider olarak sunumunda hangi mitlerin inşa edildiğini açıklaması,

- kült liderlik ve propaganda kavramları arasındaki ilişkiyi göstermesi bakımından önem taşımaktadır.

\section{Çalışmanın Evreni ve Örneklemi}

Çin Halk Cumhuriyeti'nde Mao'nun kült liderlik propagandasında kullanılan tüm posterler çalışmanın evrenini oluşturmaktadır. Buna karşın tüm posterlere ulaşmanın güçlügünnden dolayı çalışmada örneklem kullanılmıştır. Bu yolla çalışma kapsamında amaçlı örneklem metodu kullanılarak Uluslararası Sosyal Tarih Enstitüsü'nden (ISSH) seçilen sekiz propaganda posteri çalışmanın örneklemi olarak belirlenmiştir (ISSH, 2019).

\section{Çalışmanın Sınırlıııkları}

Çalışmada Mao'nun kült liderlik propagandasında posterlerin ne şekilde kullanıldığını ortaya koymak için yalnızca sekiz posterin analiz edilmesi ve elde edilen bulgular kapsamında genellemelerde bulunulması çalışmanın temel sınırlılı̆ııı oluşturmaktadır.

\section{Çalışmanın Soruları}

Çalışmada aşağıdaki sorulara yanıt aranması amaçlanmıştır;

Mao'nun kült liderlik propagandasında kullanılan Çin propaganda posterlerinde;

- hangi konular ön plana çıkarılmaktadır?

- Mao ile ilgili Çin kamuoyunda hangi propaganda mitleri inşa edilmektedir?

- hangi metafor, metonimi ve kodlardan yararlanılmıştır? 


\section{Çalışmanın Yöntemi}

Çalışmada nitel araştırma yöntemlerinden göstergebilimsel analiz yöntemi kullanılmıştır. Çalışmada seçilen sekiz Çin propaganda posteri Fransız dilbilimci Roland Barthes'ın düzanlam, yananlam, mit, metofor, metonimi kavramları üzerinden analiz edilmiştir.

Gösterge, bir kavramın başka bir kavramı temsil etmesi ve onun yerine kullanılmasını ifade etmektedir. Gösterge, insanların zihinlerinde temsil edilen kavram ile ilgili bir imaj oluşturmaktadır. Göstergebilim ise göstergeler yoluyla inşa edilen anlamlandırmaları inceleyen bir bilim dalıdır. İlk göstergebilim çalışmaları dilbilimciler Ferdinand de Saussure ve Charles Sanders Peirce'in birbirlerinden habersiz olarak yaptığı çalışmalar ile ortaya çıkmıştır (Gazi vd., 2018b, s.15). 20. yüzyılda ortaya çıkan göstergebilimin ilk başlarda dilbilimi içerisinde sınırlı bir alanı kapsadığı düşünülmekteydi. Fakat zaman içerisinde Saussure ve Peirce'in çağdaşları tarafından yapılan çalışmalar ile göstergebilimin dilbilimi alanında sınırlı bir etkisinin olmadığ ortaya çıkmış, hatta dilbilimin göstergebilim içerisinde bir alan olduğu sonucuna ulaşılmıştır. Bu süreçte Fransız dilbilimci Roland Barthes'ın (1915-1980) göstergebilim alanındaki çalışmaları göstergebilimin sinema, resim, fotoğraf, müzik gibi farklı disiplinlerde kullanılmasını sağlamıştır (Rıfat 2013, s.40-41). Saussure'ün etkisinde kalan Barthes, göstergebilim alanında Saussure'ün ortaya koyduğu kavramlara yeni kavramlar ekleyerek alanın gelişmesinde önemli rol oynamıştır.

Barthes, göstergebilim alanına pek çok yeni kavram kazandırmıştır. Bunlar içerisinde en öne çıkanlar düzanlam ve yananlam kavramları olmuştur (Barthes, 2016a, s.84). Düzanlam bir kavramın evrensel olarak hitap ettiği anlamı ifade etmektedir. Düzanlamda göstergenin ortaya koyduğu anlam herkes tarafından ortak kabul görmektedir (Barthes, 2016b, s.19). Örneğin, bir kedi düzanlam açısından incelendiğinde herkes tarafından hayvan olarak nitelendirilmektedir. Ya da bir elma düzanlam boyutunda genel kanı olarak mevte olarak adlandırılmaktadır. Yananlam ise düzanlamın ikinci boyutunu meydana getirmektedir. Yananlamda göstergenin anlamının kültürden kültüre değiștiği, öznel olduğu savunulmaktadır (Barthes, 2014, s.25). Örneğin, terazi düzanlam boyutunda bir ölçü birimini, yananlam açısından ise adalet kavramını temsil etmektedir. Bu süreçte yananlamın bir kültür içerisinde doğru okunabilmesi için göstergebilimsel analizin yapıldığı kültürün temel dinamiklerine hakim olunması gerekmektedir. Barthes, göstergebilimde göstergenin insanlar tarafından nasıl yorumlandığını ön plana çıkarmaktadır (Barthes, 2017, s.127). Diğer bir deyişle Barthes'ın göstergebilim anlayışında insanların gösterge üzerindeki yorumuna önem verilmektedir.

Barthes, bu aşamada mit kavramı üzerinde durmaktadır. Mit kelime anlamı olarak bir kültürün çevresinde şahit olduğu değişimleri ve gelişimleri yorumlayarak oluşturduğu hikayeleri ifade etmektedir. Örneğin, erkelerin evin geçimini sağlamakla yükümlü olduğu düşüncesi toplum içerisinde zamanla inşa edilmiş olan en bilinen mitlerden biridir. Mitler, zamanla kültür içerisinde kendiliğinden oluşabilirken kimi zamanda egemen güçlerin ideolojik söylemlerini hakim kılmak için medya yoluyla oluşturulabilmektedir. Medya yoluyla oluşturulan bu mitler egemen söylemin dili içerisinde hareket ederek kitleler üzerinde kontrol kurmayı amaçlamaktadır. Egemen ideolojiler bu süreçte kitle iletişim araçlarını etkili bir şekilde kullanarak neyi yapıp yapmamaları, kimi destekleyip, kime karşı olmalarına kadar pek çok 
konuda kitleleri yönlendirebilmektedir (Çak1, 2018e, s.23). Bu aşamamda ideolojik mitlerin inşasında medyanın kontrolünün kimin elinde olduğu önemli bir konudur. Nitekim medya üzerinde etkili olanlar, toplum içerisindeki mitlerin inşasında da doğrudan etkili olabilmektedir. Barthes, bu süreçte göstergebilimin egemen ideolojinin toplumdaki dilini analiz ettiğini savunmaktadır (Barthes, 2015, s.57). Barthes, yananlam ve mit kavramlarını, düzanlamın ikinci düzeyi olarak nitelendirmektedir. Bu aşamada, Barthes Saussure'ün Göstergeler Modeli'nde yer alan gösteren ve gösterilen kavramlarına da aracı bir rol vermektedir. Gösteren, bir kavramın nesnel anlamını, gösterilen ise öznel içeriğini ifade etmektedir (Kalkan Kocabay, 2008, s.16). Örneğin, bir kişinin başka bir kişiye sunduğu gül gösteren açıdan bakıldığında sıradan bir çiçek olarak değerlendirilebilirken, gösterilen açıdan aşk ve sevgi kavramlarını temsil edebilmektedir. Diğer yandan Barthes'ın göstergebilim anlayışı özelinde yapılan analizlerde metafor ve metonimi kavramları da ön plana çıkabilmektedir (Çakı vd., 2019, s.59). Metafor, bir kavramın başka bir kavramın yerine eğreti biçimde kullanılmasını; metonimi ise birbirleri ile az veya çok bağlantı bulunan iki kavramdan birinin diğeri yerine kullanılmasını ifade etmektedir (Guiraud, 2016, s.145-146).

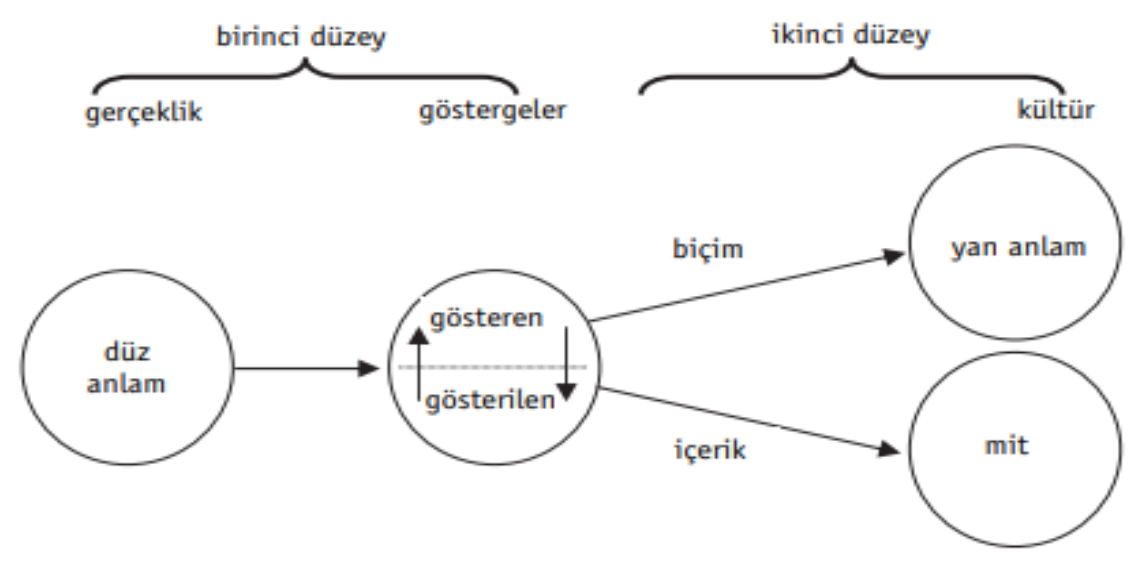

Şekil 1. Roland Barthes'in Anlamlandırma Modeli

Kaynak: Fiske, 2017: 186

Çalışma kapsamında incelenen Çin propaganda posterlerinde ülkede egemen olan ideolojinin Barthes'ın göstergebilim anlayışı çerçevesinde Mao'yu kült lider olarak nasıl inşa etmeye çalıştığı detaylı olarak analiz edilmeye çalışılmıştır.

\section{Analiz}

Çalışmanın bu bölümünde "'Sanayi", "Aile", "Asker", "Kültür", "Sevgi", "Büyük Lider", "Kitap" ve "Rapor" konulu sekiz propaganda posteri göstergebilimsel açıdan analiz edilmiştir.

\section{"Sanayi" Konulu Propaganda Posteri}

"Sanayi" konulu propaganda posteri 1954 yılına aittir. Poster düzanlam açısından incelendiğinde, posterde Mao'nun Çin'deki fabrikaların önünde olduğu aktarılmaktadır. Görsel kodlar içerisinde Mao'nun neşeli olduğu, bir elinde bir kağıt rulosunu tuttuğu, diğer elini de 
havaya kaldırdığı görülmektedir. Mao'nun arkasında aynı zamanda bir tren ve askeri araçların olduğu da aktarılmaktadır. Mao'nun hemen önünde başak taneleri ve çeşitli meyvelerin bulunduğu resmedilmektedir. Posterin hemen altında "Çin'i, Komünist Parti ve lider Mao'nun önderliğinde müreffeh, zengin ve güçlü bir sanayileşmiş sosyalist ülkeye dönüştürün!" yazılı kodu bulunmaktadır.

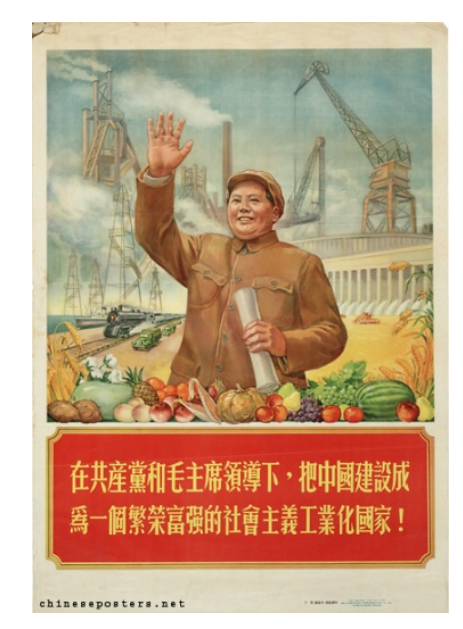

Resim1. "Sanayi" Konulu Propaganda Posteri

Kaynak: IISH, 2019

Poster yananlam boyutunda analiz edildiğinde, posterde Mao liderliğinde Çin halkının refah bir yaşama kavuşacağı mesajı verilmektedir. Posterde yer alan başak taneleri ve meyve görselleri Çinli köylülerin, fabrika ve tren görselleri Çinli iş̧̧ilerin ve askeri araçlar da Çinli askerlerin metonomi olarak postere yansıtılmaktadır. Çin'in posterin merkezine konumlandırılması ile Mao'nun Çinli köylülere, iş̧̧ilere ve askerlere liderlik yaptı̆̆ı mesajı verilmeye çalışılmaktadır. Posterdeki görsel kodlarda Mao liderliğindeki Çin, zengin bir tarım ülkesi, gelişmiş teknolojiye sahip sanayi ülkesi ve güçlü bir orduya sahip dünya gücü olarak yansıtılmaktadır. Posterde Mao bu açıdan doğrudan refah metaforu olarak ön plana çıkarılmaktadır. Posterdeki yazılı kodlarda da Komünist Parti'ye ve sosyalizme vurgu yapılması ile Mao'nun ideolojik söylemler üzeriden kült lider olarak inşa edilmesi amaçlanmıştır. Posterdeki yazılı ve görsel kodlar bir bütün olarak değerlendirildiğinde, posterde "Çin, Mao liderliğinde refah içerisinde yaşamaktadır" şeklinde propaganda mitinin inşa edilmeye çalışıldığı ortaya çıkmaktadır. Böylece Çin propagandası, Çin halkının refah bir ülkede yaşayabilmesi için Mao'nun liderliğinde hareket etmesi gerektiğini telkin etmiştir.

Tablo 1. "Sanayi" Konulu Propaganda Posteri

\begin{tabular}{|l|r|}
\hline Düzanlam & Fabrikaların önünde Mao'nun el sallaması \\
\hline Gösteren & Çin'deki fabrikalar ve Mao \\
\hline Gösterilen & Refah, mutluluk, huzur, gelişme \\
\hline Yananlam & Mao liderliğinde Çin halkının refah bir yaşama kavuşacağı düşüncesi \\
\hline Mit & Çin, Mao liderliğinde refah içerisinde yaşamaktadır \\
\hline Metafor & Mao, refah metaforu olarak kullanılmaktadır \\
\hline Metonimi & Posterde yer alan fabrikalar, Çin'deki tüm üretim tesislerinin metonimi olarak \\
kullanılmaktadır
\end{tabular}




\section{"Aile" Konulu Propaganda Posteri}

"Aile" konulu propaganda posteri 1954 yılına aittir. Poster düzanlam boyutunda ele alındığında, posterde yemek yemekte olan bir Çinli ailenin resmine yer verilmiştir. Görsel kodlarda ailenin yemek yediği salonun merkezinde de Mao'nun resmi yer almaktadır. Posterde tüm aile üyeleri neşeli olarak yansitılmaktadır. Posterin hemen üstünde "Lider Mao bize mutlu bir hayat veriyor" yazılı kodu bulunmaktadır.

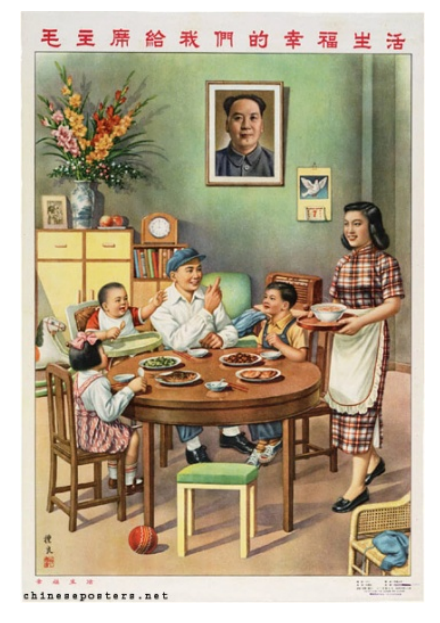

Resim 2. "Aile" Konulu Propaganda Posteri

Kaynak: IISH, 2019

Yananlam açısından incelendiğinde, posterde Çin halkının Mao'nun liderliğinde mutlu ve huzurlu yaşadığı mesajı verilmeye çalışılmaktadır. Çinli aile tüm Çin halkının metonimi olarak kullanılmaktadır. Bu açıdan Çinli ailenin evinin baş köşesinde Mao'nun resminin bulunması ile Çin halkının Mao'ya büyük önem atfettiği aktarılmaktadır. Posterde "Mao'nun öğretileri doğrultusunda hareket eden Çin halkı mutluluğa ulaşır" şeklinde propaganda miti inşa edilmeye çalışılmaktadır. Bu şekilde Mao, posterde huzur metaforu olarak yansıtılmaktadır. Çin halkının Mao'nun liderliğinden ayrılmadan onun koyduğu kurallar çerçevesinde yaşaması istenmektedir. Çin propagandası, Çinli ailelerin günlük yaşantılarında bile, hatta mahremleri olarak kabul edilen evlerinde bile Mao'nun öğretileri doğrultusunda yaşadığı ve Mao'ya olan sevgi ve saygılarından dolayı Mao'nun resmini evlerinin baş köşesine astığı şeklinde bir algı oluşturmaya çalışmaktadır. Yazılı kodlar üzerinden de görsel kodlar desteklenmekte ve Çin halkının huzur ve mutluluğundan dolayı Mao'ya minnet duyduğu aktarılmaktadır. 


\section{Tablo 2. "Aile" Konulu Propaganda Posteri}

\begin{tabular}{|l|c|}
\hline Düzanlam & Çinli ailenin Mao'nun resmi altında yemek yemesi \\
\hline Gösteren & Çinli bir aile ve Mao \\
\hline Gösterilen & Huzur, Mutluluk, Neşe \\
\hline Yananlam & Çinli aile Mao'nun liderliğinde mutlu bir hayat sürmektedir \\
\hline Mit & Mao'nun öğretileri doğrultusunda hareket eden Çin halkı mutluluğa ulaşır \\
\hline Metafor & Mao, huzur metaforu olarak kullanılmaktadır \\
\hline Metonimi & Çinli aile tüm Çin halkının metonimi olarak kullanılmaktadır \\
\hline
\end{tabular}

\section{"Asker" Konulu Propaganda Posteri}

"Asker" konulu propaganda posteri 1966 yılına aittir. Poster düzanlam açısından incelendiğinde, posterde elinde Mao'nun kitabı bulunan Çinli bir asker resmedilmektedir. Sunum kodları içerisinde askerin kararlı bir şekilde bir yöne doğru baktığı aktarılmaktadır. Askerin çevresinde de farklı açlardan başka Çinli askerlere yer verilmiştir. Bunlardan ilkinde Mao'nun kitabını okuyan askerler, diğerinde tarlada çalışan askerler, sonuncusunda da kızıl bayrak ile bir yöne doğru saldırıya geçen askerler yansıtılmaktadır. Posterin arka fonunda da kırmızı renk kullanılmaktadır. Posterin hemen altında "Savaşçılar, lider Mao'nun kitaplarını okumayı çok seviyor" yazılı kodu bulunmaktadır.

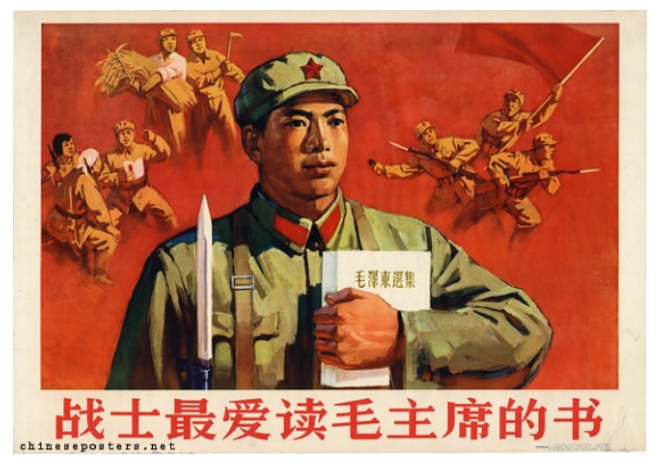

Resim 3. "Asker" Konulu Propaganda Posteri

Kaynak: IISH, 2019

Poster yananlam boyutunda analiz edildiğinde, posterde Çin ordusunun Mao'ya olan bağlılığının yansıtılmaya çalışıldığı görülmektedir. Posterde resmedilen Çinli asker, tüm Çin ordusunun metonimi olarak kullanılmaktadır. Çinli askerin Mao'nun kitabını sıkı sıkıya tutması, Çin ordusunun Mao'nun ideolojik söylemleri doğrultusunda hareket ettiğini yansıtmaktadır. Posterin merkezindeki asker görselinin çevresinde bulunan diğer asker görselleri üzerinden de üç temel mesaj verilmeye çalışılmaktadır. Bunlardan ilk Çinli askerlerin Mao'nun öğretilerini sürekli olarak hatırladıkları, ikincisi Çinli askerlerin aynı zamanda üretime de katıldığı, üçüncüsü ise Çinli askerlerin komünizm ideolojisi için savaştığı şeklindedir. Posterde Çinli askerlerin savaşçı yapılarının Mao'nun düşünceleri çerçevesinde şekillendiği aktarılmaktadır. Bu açıdan posterde "Çin ordusu Mao'nun öğretileri doğrultusunda hareket etmektedir" şeklinde propaganda miti inşa edilmektedir. Çin propagandası, poster üzerinden Çin ordusunun doğrudan Mao'yu rehber aldığı ve Mao'ya sonuna kadar sadık olduğu mesajını vermeye çalışmaktadır. 
Tablo 3. "Asker" Konulu Propaganda Posteri

\begin{tabular}{|l|c|}
\hline Düzanlam & Mao'nun kitabına sarılan Çinli bir asker \\
\hline Gösteren & Çinli asker ve Mao'nun kitabı \\
\hline Gösterilen & Güç, zafer, otorite, başarı \\
\hline Yananlam & Çin ordusunun Mao'ya sadakatle bağlı olması \\
\hline Mit & Çin ordusu Mao'nun öğretileri doğrultusunda hareket etmektedir \\
\hline Metafor & Mao, zafer metaforu olarak kullanılmaktadır \\
\hline Metonimi & Çinli asker, tüm Çin ordusunun metonimi olarak kullanılmaktadır \\
\hline
\end{tabular}

\section{"Kültür" Konulu Propaganda Posteri}

"Kültür" konulu propaganda posteri 1966 yılına aittir. Poster düzanlam boyutunda ele alındığında, posterde farklı etnik ve kültürel yapıdaki Çin vatandaşlarının kızıl bayraklar altında yürüdükleri yansıtılmaktadır. Posterde resmedilen herkesin mutlu olduğu aktarılmaktadır. Posterin merkezinde ise Mao'nun gülerken yer aldığ ${ }_{1}$ bir resmine yer verilmiştir. Posterin sol üst köşesinde "Mao Zedong düşüncesinin güneş 1şığı, büyük proleter Kültür Devrimi'nin yolunu aydınlatıyor" yazılı kodu bulunmaktadır.

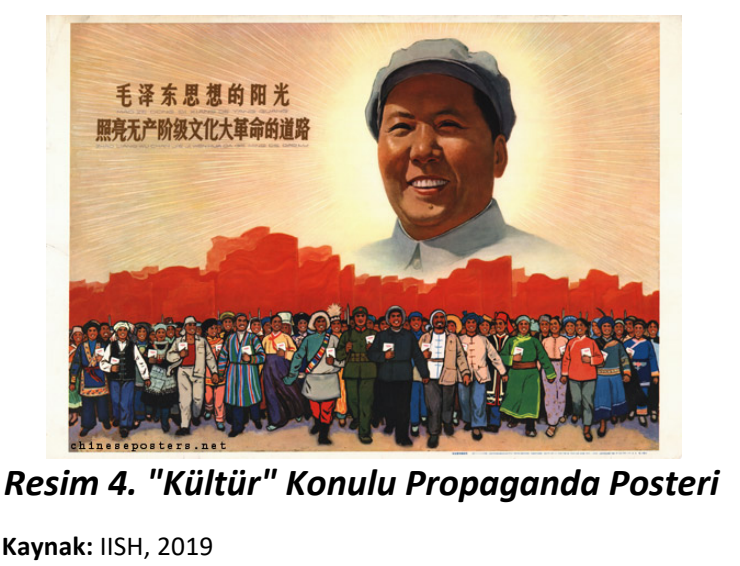

Yananlam açısından incelendiğinde, posterde Mao'nun gerçekleştirdiği Çin Kültür Devrimi'nin ülkedeki iç huzuru sağladığı mesajının verilmeye çalışıldığ 1 görülmektedir. Posterdeki görsel kodlarda, Çin'de yaşayan farklı etnik grupların bir araya geldiği aktarılmaktadır. Tüm etnik grupların bir araya gelmesini sağlayan unsur olarak da Mao gösterilmektedir. Posterde Mao'nun devasa boyutta yer verilen resmi, Mao'nun Çin halkına liderlik ettiği algısını oluşturmaktadır. Diğer yandan posterde resmedilen kızıl bayraklar ile de Çin halkının doğrudan komünizm ideolojisi altında yaşadığı vurgusu yapılmaktadır. Posterde Çin halkının ellerinde Mao'nun kitapları ile resmedilmesi, Çin halkının Mao'nun öğretileri doğrultusunda hareket ettiği düşüncesini meydana getirmektedir. Posterdeki yazılı kod üzerinden verilen mesaj, görsel kodlarla birlikte "Mao'nun Kültür Devrimi'nden tüm Çin halkı memnundur" şeklindeki propaganda mitini inşa etmektedir. Böylece Mao'nun gerçekleştirdiği devrimin toplumun her kesiminden destek gördügü belirtilerek, devrimin ülkede meşruiyetinin sağlanması amaçlanmaktadır. 
Tablo 4. "Kültür" Konulu Propaganda Posteri

\begin{tabular}{|c|c|}
\hline Düzanlam & $\begin{array}{c}\text { Çin'in farklı etnik ve kültürel yapısını temsil eden insanların kızıl bayraklar ile } \\
\text { ilerlemesi }\end{array}$ \\
\hline Gösteren & Kızıl bayraklar, Çin halkı ve Mao \\
\hline Gösterilen & Güç, otorite, mutluluk, barış \\
\hline Yananlam & $\begin{array}{l}\text { Mao'nun başlatmış olduğu Kültür Devrimi ile ülkede birlik, barış ve huzur } \\
\text { sağlanmıştır }\end{array}$ \\
\hline Mit & Mao'nun Kültür Devrimi'nden tüm Çin halkı memnundur \\
\hline Metafor & Mao, güç metaforu olarak kullanılmaktadır \\
\hline Metonimi & Posterde yer alan kişiler tüm Çin halkının metonimi olarak kullanılmaktadır \\
\hline
\end{tabular}

\section{"Sevgi" Konulu Propaganda Posteri}

"Sevgi" konulu propaganda posteri 1968 yllına aittir. Poster düzanlam açısından incelendiğinde, posterde Mao'nun bir tarlanın önünde yer aldığı aktarılmaktadır. Görsel kodlarda Mao'nun asker üniforması içerisinde olduğu yansıtılmaktadır. Mao'nun hemen arkasında da güneş resmedilmektedir. Posterin hemen altında "Sayglarımla, lider Mao'nun ebedi hayatını diliyorum" yazılı kodu bulunmaktadır.

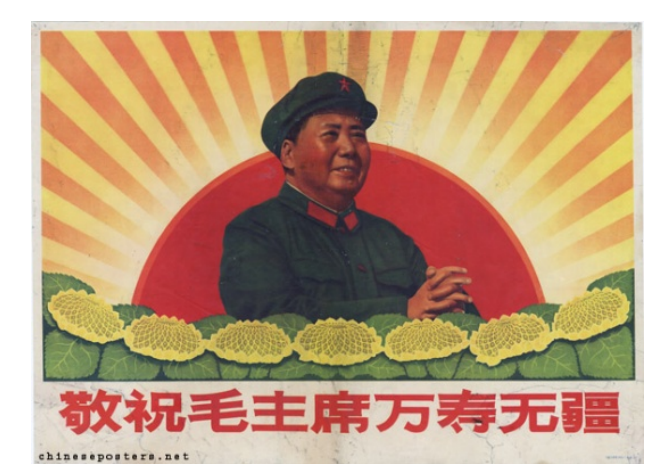

Resim 5. "Sevgi" Konulu Propaganda Posteri

Kaynak: IISH, 2019

Poster yananlam boyutunda analiz edildiğinde, posterde iki temel mesajın verildiği aktarılmaktadır. Birincisi Çin halkının Mao'ya olan derin sevgisi, ikincisi ise Mao liderliğinde Çin'de meydana gelen refah ve bolluk mesajlarıdır. Bu açıdan posterde "Çin halkının Mao'ya olan sevgisi süreklidir" şeklinde propaganda miti inşa edilmeye çalışılmaktadır. Posterde Mao'nun güneşin önünde resmedilmesi, Mao liderliğinde Çin'in güçlü ve refah bir devlet olduğuna vurgu yapmaktadır. Posterdeki yazılı kodlar üzerinden Çin halkının tümüyle Mao'ya sadık olduğu ve Mao'nun liderliğinden memnun oldukları mesajları verilmektedir. Böylece Çin propagandası, Mao'yu milyonların sevdiği efsanevi bir lider olarak sunmaya çalışmaktadır. 
Tablo 5. "Sevgi" Konulu Propaganda Posteri

\begin{tabular}{|l|c|}
\hline Düzanlam & Mao'nun tarlanın önünde durması \\
\hline Gösteren & Tarla ve Mao \\
\hline Gösterilen & Sevgi, Bağlılık, Sadakat \\
\hline Yananlam & Çin halkının tümü Mao'yu sevmektedir \\
\hline Mit & Çin halkının Mao'ya olan sevgisi süreklidir \\
\hline Metafor & Mao, bolluk metaforu olarak kullanılmaktadır \\
\hline Metonimi & Tarla, tüm Çin'deki üretimi temsil etmektedir \\
\hline
\end{tabular}

\section{"Büyük Lider" Konulu Propaganda Posteri}

"Büyük Lider" konulu propaganda posteri 1969 yllına aittir. Poster düzanlam boyutunda ele alındığında, posterde kızıl bayraklar ile bir yöne doğru ilerlemekte olan Çin halkı ve Çin askerleri resmedilmektedir. Posterin merkezinde ise Mao'nun resmine yer verilmektedir. Görsel kodlar içerisinde Çin halkının ve askerlerinin resimleri oldukça küçük aktarılırken, Mao'nun resmi devasa olarak gösterilmektedir. Mao'nun kararlı bir şekilde bir yöne doğru baktığı yansıtılmaktadır. Posterin hemen altında "Büyük lider Mao'yu takip ederken cesurca yol gösterici olmak!" yazılı kodu yer almaktadır.

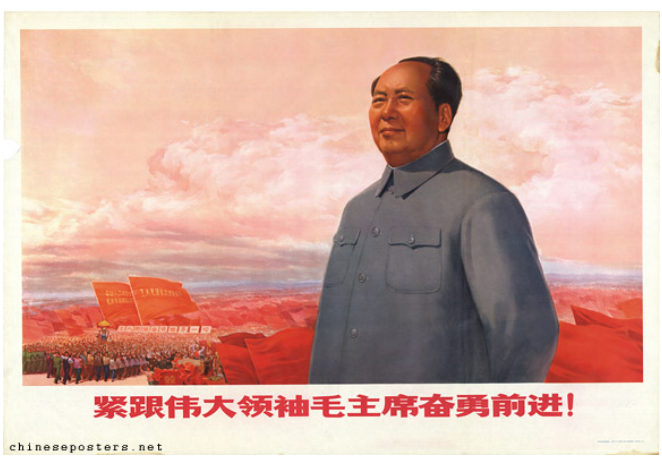

Resim 6. "Büyük Lider" Konulu Propaganda Posteri

Kaynak: IISH, 2019

Yananlam açısından incelendiğinde, posterde Çin halkının Mao liderliğinde hareket ettiği mesajı verilmektedir. Posterdeki görsel kodlarda Çin halkının kızıl bayraklar taşıması, Çin halkının komünizm ideolojisi doğrultusunda hareket ettiğini vurgulamaktadır. Posterde Mao'nun devasa görseline yer verilmesi ve Çin halkının uzaktan küçük olarak aktarılması, Mao'nun Çin halkı üzerindeki gücü ve otoritesinin bir yansıması olarak sunulmaktadır. Çin halkının demokratik bir rejimden ziyade tamamen Mao'nun kült liderliği altında yönetildiği mesajı verilmektedir. Bu şekilde Mao'nun ülkede tüm kontrolü elinde bulundurduğu aktarılmakta, Çin halkının da bunu gönülden istediği şeklinde bir algı inşa edilmeye çalışılmaktadır. Bu çerçevede poster üzerinden "Mao, Çin halkına liderlik yapacak tek kişidir" propaganda miti oluşturulmak istenmektedir. Çin propagandası yazılı kodlar üzerinden de Mao yönetiminin ülkedeki meşruluğunu sağlamayı hedeflemektedir. 
Tablo 6. "Büyük Lider" Konulu Propaganda Posteri

\begin{tabular}{|l|c|}
\hline Düzanlam & Kızıl bayraklar taşıyan Çin halkının Mao'nun arkasından ilerlemesi \\
\hline Gösteren & Kızıl bayraklar, Çin halkı ve Mao \\
\hline Gösterilen & Liderlik, cesaret, güç, otorite \\
\hline Yananlam & Çin halkının Mao'nun liderlik gücüne inanması \\
\hline Mit & Mao, Çin halkına liderlik yapacak tek kişidir \\
\hline Metafor & Mao, cesaret metaforu olarak kullanılmaktadır \\
\hline Metonimi & Posterde yer alan kişiler tüm Çin halkının metonimi olarak kullanılmaktadır \\
\hline
\end{tabular}

\section{Kitap" Konulu Propaganda Posteri}

"Kitap" konulu propaganda posteri 1970 yılına aittir. Poster düzanlam açısından incelendiğinde, posterde ellerinde Mao'nun kitabı bulunan Çin halkının bir yöne doğru baktığı aktarılmaktadır. Görsel kodlar içerisinde hepsinin de yüzünün güldügü yansitılmaktadır. Posterin arkasında da kızıl bayraklar konumlandırılmaktadır. Posterin hemen altında "Yaşasın lider Mao! Çok uzun yaşa!" yazılı kodu bulunmaktadır.

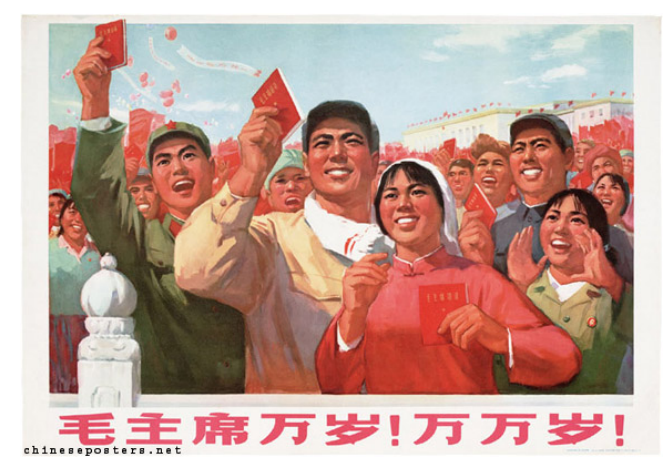

\section{Resim 7. "Kitap" Konulu Propaganda Posteri}

Kaynak: IISH, 2019

Poster yananlam boyutunda analiz edildiğinde, posterde Mao'nun öğretilerinin Çin halkı tarafından benimsendiği mesajının verilmeye çalışıldığı görülmektedir. Posterde resmedilen Çin halkının yüzündeki gülümseme ve ellerindeki Mao'nun kitapları, Mao liderliğinde Çin halkının huzur ve mutluluğa ulaştığı algısını oluşturmaktadır. Diğer yandan Çin halkının sadakatle Mao'ya bağlı oldukları mesajının da verilmeye çalışıldığı görülmektedir. Nitekim posterde Çin halkının Mao'nun öğretileri doğrultusunda hareket ettikleri ve yazılı kodlar da belirtildiği gibi Mao'nun çok daha uzun bir süre liderlik yapmasını istedikleri mesajı verilmektedir. Posterde bu nedenle Mao, sevgi metaforu olarak kullanılmaktadır. Çalışma kapsamında incelenen diğer propaganda posterlerinde olduğu gibi Çin propagandası bu posterde de Mao yönetiminin meşruluğunu sağlamaya çalışmaktadır. 
Tablo 7. "Kitap" Konulu Propaganda Posteri

\begin{tabular}{|l|c|}
\hline Düzanlam & Çin halkının Mao'nun kitabını taşıması \\
\hline Gösteren & Çin halkı ve Mao'nun kitabı \\
\hline Gösterilen & Mutluluk, sevgi, inanç, bağııık \\
\hline Yananlam & Çin halkının Mao'nun liderliğinden mutlu olması \\
\hline Mit & Çin halkı Mao'ya sadakatle bağlıdır \\
\hline Metafor & Mao, sevgi metaforu olarak kullanılmaktadır \\
\hline Metonimi & Posterde yer alan kişiler tüm Çin halkının metonimi olarak kullanılmaktadır \\
\hline
\end{tabular}

\section{"Rapor" Konulu Propaganda Posteri}

"Rapor" konulu propaganda posteri 1974 yılına aittir. Poster düzanlam boyutunda ele alındığında, posterde Mao'nun Çinli çocukların yanında olduğu ve bir kağıdı okuduğu aktarılmaktadır. Görsel kodlar içerisinde çocukların mutlu olduğu ve topladıkları sebzeleri Mao'ya gösterdikleri yansitılmaktadır. Posterde "Lider Mao'ya rapor vermek" yazılı kodu bulunmaktadır.

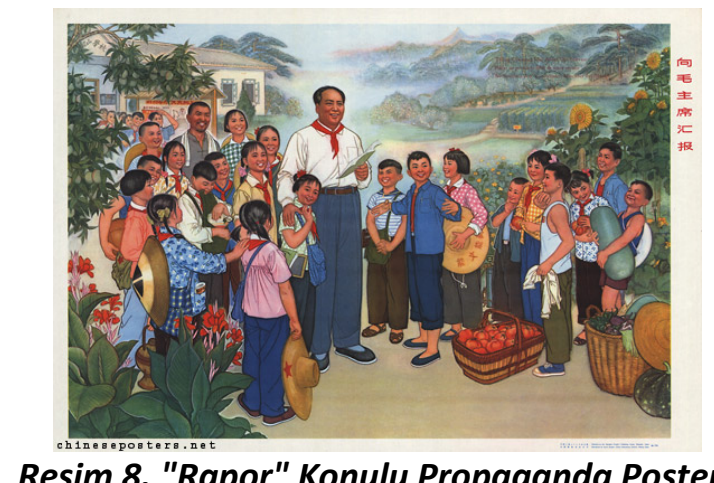

Resim 8. "Rapor" Konulu Propaganda Posteri

Kaynak: IISH, 2019

Yananlam açısından incelendiğinde, posterde Çin'deki gelecek nesillerin de Mao'nun liderliğinde hareket edeceği mesajı verilmeye çalışılmaktadır. Mao'nun sade bir kıyafetle Çinli çocukların yanında durması ve elindeki kağıtla onları denetlemesi, Çin halkının Mao'nun öğretileri doğrultusunda hareket edip etmediğinin incelendiğini aktarmaktadır. Çocukların, Mao'nun yanında mutlu sunulması ile "Çinli gelecek nesiller, Mao'nun öğretileri doğrultusunda hareket etmektedir" şeklinde propaganda miti posterde inşa edilmektedir. Çinli çocukların Mao'ya sadakatle bağlı oldukları aktarılmakta ve onun öğretileri doğrultusunda eğitim aldıkları belirtilmektedir. Çin propagandası bu şekilde, Mao'nın öğretilerinin ölümünden sonra da Çin'de etkili olacağı ve Çin halkının Mao'nun öğretileri doğrultusunda çalışacağı mesajlarını vermektedir. 
Tablo 8. "Rapor" Konulu Propaganda Posteri

\begin{tabular}{|l|c|}
\hline Düzanlam & Mao'nun Çinli çocukların yanında durması \\
\hline Gösteren & Çinli çocuklar ve Mao \\
\hline Gösterilen & Sevgi, bağlııı, neşe \\
\hline Yananlam & Çinli çocuklar Mao'yu sevmektedir \\
\hline Mit & Çinli gelecek nesiller, Mao'nun öğretileri doğrultusunda hareket etmektedir \\
\hline Metafor & Mao, bağılılık metaforu olarak kullanılmaktadır \\
\hline Metonimi & Posterde yer alan çocuklar tüm Çinli çocukların metonimi olarak \\
kullanılmaktadır
\end{tabular}

\section{Sonuç}

Çalışma kapsamında incelenen propaganda posterlerinde, Çin propagandasının doğrudan Mao'nun liderlik kültünün ülke genelinde meşruluğunun sağlanması için çalıştı̆̆ı sonucunu ortaya çıkarılmıştır. Posterler üzerinden resmedilen kişilerin tüm Çin halkının metonimi olarak kullanılması amaçlanmış ve kullanılan metonimiler üzerinden Çin halkının Mao'nun liderliğine sadakatle bağlı olduğu aktarılmıştır. Posterlerdeki görsel kodlarda Çin halkının Mao'nun yönetiminde refah, huzur, barış ve bolluk içerisinde yaşadıkları belirtilmiştir. Yine görsel kodlarda Mao'nun posterlerde devasa boyutta gösterilmesi, Mao'nun Çin halkı üzerindeki otoritesi ve gücünün temsili olarak yansıtılmıştır. Diğer yandan kullanılan yazılı kodlar üzerinden de sıklıkla "Çin halkı Mao'yu sever ve ona sadıktır" mesajının verilmeye çalışıldı̆̆ı görülmüştür.

Posterler üzerinden yapılan analizlerde Çin propagandası tarafından, "Çin halkı, Mao liderliğinde refah içerisinde yaşamaktadır", "Mao'nun öğretileri doğrultusunda hareket eden Çin halkı mutluluğa ulaşır", "Mao, Çin halkına liderlik yapacak tek kişidir", "Çin halkı Mao'ya sadakatle bağlıdır" vb. şeklinde propaganda mitlerinin inşa edilmeye çalışıldığı görülmüştür. Çin propagandası inşa edilen propaganda mitleri üzerinden Mao'nun ülke genelinde büyük bir halk desteğine sahip olduğu mesajını vermeye çalışmaktadır. Böylece Mao'ya karşı oluşabilecek herhangi bir muhalefetin marjinalleştirilerek ortadan kaldırılması amaçlanmıştır. Mao kültü ile ülkede tek sesliliğin gelmesi ve yönetime karşı olabilecek hiç bir kişi veya grubun muhalefetine izin verilmemesi hedeflenmiştir.

Posterlerde Çin'in yalnızca Mao'nun yönetimi ile güçlü ve refah bir ülke olabileceği aktarılmaya çalışılmıştır. Bu aşamada Mao kültünün etkisinin yayılabilmesi için de Mao'nun "Kırmızı Kitap"ının Çinliler tarafından okunması gerektiği telkin edilmiştir. Nitekim posterlerdeki Mao'nun kitabını okuyan Çinlilerin mutlu, huzurlu ve başarılı olduğu mesajları verilmiştir. Çin propagandası bu şekilde Mao yönetiminin Çin halkı üzerinde tamamen kontrol kurmasını amaçlamış ve Çin halkının Mao'nun emirlerini sorgulamadan uygulamasını istemiştir. Böylece Mao yönetimince alınan kararlarda halk desteğinin sağlanması ve Mao'nun ülkeyi çok daha kolay bir şekilde yönetmesi amaçlanmıştır.

Mao'nun posterler üzerindeki kült liderlik propagandasında dinsel söylemlere yer verilmediği görülmüştür. Bu açıdan çalışmada elde edilen bulgular, "kült liderlik propagandasında dinsel söylemler kullanılmaktadır" şeklinde sonuç bildiren çalışmaları (Çakı, 2018a; Çakı ve Gülada, 
2018) desteklememektedir. Buna karşın Çin'in resmi ideolojisi olan komünizmin posterlerde sıklıkla yer aldığı saptanmıştır. Buradan hareketle çalışma "kült liderlik propagandasında ideolojik söylemler etkili olarak kullanılır" şeklinde sonuç bildiren çalışmaları destekler mahiyette bulgulara ulaşmıştır (Çakı, 2018b; Karaca, 2018; Gazi vd., 2018).

Çalışmada Çin'de kullanılan propaganda posterlerinde Mao'nun kült lider olarak nasıl inşa edilmeye çalışıldığı ortaya konulmaya çalışılmıştır. Gelecek çalışmalarda Mao'nun kült liderlik propagandasının farklı kitle iletişim araçları üzerindeki yansımasının, mevcut çalışmada elde edilen bulgular ile karşılaştırmalı olarak incelenmesinin alana katkı sağlayacağı düşünülmektedir.

\section{Kaynakça}

Aziz, A. (2007). Siyasal İletişim. (2. Bask1). Ankara: Nobel.

Barmé, G. (2016). Shades of Mao: The Posthumous Cult of the Great Leader: The Posthumous Cult of the Great Leader. The Great Britain: Routledge.

Barthes, R. (2014). Çă̆gaş Söylenler. Tahsin Yücel (Çev.), (4. Baskı). İstanbul: Metis.

Barthes, R. (2015). Bir Deneme Bir Ders: Eiffel Kulesi ve Açılış Dersi. Mehmet Rifat, Sema Rifat (Çev.), (2. Baskı). İstanbul: Yapı Kredi.

Barthes, R. (2016a). Göstergebilimsel Serüven. Mehmet Rifat, Sema Rifat. (Çev.), (8. Baskı). İstanbul: Yapı Kredi.

Barthes, R. (2016b). S/Z. Sündüz Öztürk Kasar (Çev.). İstanbul: Sel.

Barthes, R. (2017). Görüntünün Retoriği, Sanat ve Müzik. Ayşenaz Koş, Ömer Albayrak (Çev.), (2. Baskı). İstanbul: Yapı Kredi.

Çakı, C. (2018a). Adolf Hitler'in kült lider inşasında kullanılan propaganda posterlerinin göstergebilimsel analizi. Abant Kültürel Araştırmalar Dergisi, 3(6), 24-38.

Çakı, C. (2018b). Komünizm ideolojisinde kült lider olgusu: "Berlin'in Düşüşü" propaganda filmi'nin alımlama analizi. Ege Üniversitesi İletişim Fakültesi Yeni Düşünceler Hakemli E-Dergisi, (9), 94-113.

Çakı, C. (2018c). Propaganda. Mustafa Karaca ve Caner Çakı (Ed.), İletişim ve Propaganda içinde (s. 13-44). Konya: Eğitim.

Çakı, C. (2018d). Birinci Dünya Savaşı'ndaki Alman Propaganda Kartpostallarında Kullanılan Karikatürlerde Türklerin Sunumunun Göstergebilimsel Açıdan İncelenmesi. Akdeniz Üniversitesi İletişim Fakültesi Dergisi, (29), 73-94. 
Çakı, C. (2018e). İran-Irak Savaşı'nda Kullanılan İran Propaganda Posterlerinin Göstergebilimsel Analizi. İran Çalışmaları Dergisi, 2(1), 11-39.

Çakı, C., Gülada, M. O., \& Çakı, G. (2019). Balkanlarda Bir Nazi Ordusu: Nazi Propaganda Afişlerinde Hançer Tümeni. Trakya Üniversitesi İktisadi ve İdari Bilimler Fakültesi Dergisi, 7(2), 55-77.

Çakı, C., \& Gülada, M. O. (2018). Duvar Resimleri Üzerinden Kült Liderlik Propagandası: Irak Devlet Başkanı Saddam Hüsseyin Üzerine İnceleme. Dördüncü Kuvvet Uluslararası Hakemli Dergi, 1(2), 7-24.

Domenach, J. M. (2003). Politika ve Propaganda. Tahsin Yücel (Çev.). İstanbul: Varlık.

Fiske, J. (2017). İletişim Çalışmalarına Giriş. Süleyman İrvan (Çev.), (5. Baskı). Ankara: Bilim ve Sanat.

Gaddins, J. L. (2018). Soğuk Savaş, Pazarlıklar, Casuslar, Yalanlar, Gerçek, Dilek Cenkçiler (Çev.), (3. Baskı), İstanbul: Yapı Kredi.

Gazi, M. A., Çakı, C., \& Gülada, M. O. (2018a). İkinci Dünya Savaşı'nda Sovyet Kült Lider Propagandasında Vladimir Lenin ve Joseph Stalin'in Sunumu. Dördüncü Kuvvet Uluslararası Hakemli Dergi, 1(2), 25-42.

Gazi, M. A., Çakı, C. \& Gülada, M. (2018b). İspanya 2000 Partisi'nin Göçmen Karşıtı Propaganda Faaliyetleri Üzerine İnceleme. Ankara Uluslararası Sosyal Bilimler Dergisi, 1(2), 11-22.

Gill, G. (1980). The Soviet Leader Cult: Reflections on the Structure of Leadership in the Soviet Union. British Journal of Political Science. 10(2). 167-186.

Goldberg, L. (1997). A Psychoanalytic Look at Recovered Memories, Therapists, Cult Leaders, and Undue İnfluence. Clinical Social Work Journal. 25(1), 71-86.

Guiraud, P. (2016). Göstergebilim. Mehmet Yalçın (Çev.), (3. Baskı). Ankara: İmge.

Gundle, S., D. C. \& Pieri, G. (2015). The Cult of the Duce: Mussolini and the Italians. United Kingdom: Oxford University Press.

IISH (2019). Çin Propaganda Posterleri, https://search. social history. org/Search /Results? \&format \%3A\%22 Visual+ documents \%22\&lookfor= China+ poster+ Mao+TseTung, Erişim Tarihi: 21.03.2019.

Jowett, S. G. \& O'donnell, V. (2014). Propaganda \& Persuasion. USA: Sage.

Kalkan Kocabay, H. (2008). Tiyatroda Göstergebilim. İstanbul: E. 
Karaca, M. (2018). İtalyan propagandasında kült lider olgusu: "Il Duce" Benito Mussolini. Gümüşhane Üniversitesi İletişim Fakültesi Elektronik Dergisi, 6(2), 1203-1220.

Kissinger, H. (2010). Diplomasi. İbrahim H. Kurt (Çev.), (9. Baskı). İstanbul: Türkiye İş Bankasi.

Koch, N. (2016). The "Personality Cult" problematic: Personalism and mosques memorializing the "Father of the Nation" in Turkmenistan and the uae. Central Asian Affairs, 3(4), 330-359.

Lago, F. D. (1999). Personal Mao: Reshaping an icon in contemporary Chinese art. Art Journal, 58(2), 46-59.

Landsberger, S. R. (1996). Mao as the Kitchen God: Religious aspects of the Mao cult during the cultural revolution. China Information, 11(2-3), 196-214.

Leese, D. (2007). The Mao cult as Communicative Space. Totalitarian Movements and Political Religions, 8(3-4), 623-639.

Leese, D. (2011). Mao cult: Rhetoric and Ritual in China's Cultural Revolution. The United Kingdom: Cambridge University.

Luqiu, L. R. (2016). The reappearance of the cult of personality in China. East Asia, 33(4), 289-307.

Mcmahon, J. R. (2013). Soğuk Savaş, Sinem Gül (Çev.). Ankara: Dost Kültür.

Melnick, A. J. (1976). Soviet Perceptions of the Maoist cult of personality. Studies in Comparative Communism, 9(1-2), 129-144.

Paltiel, J. T. (1983). The cult of personality: Some comparative reflections on political culture in Leninist regimes. Studies in Comparative Communism, 16(1-2), 49-64.

Priestland, D. (2017). Kızıl Bayrak Bir Komünizm Tarihi, Ali Çakıroğlu, Egemen Yılgür (Çev.). İstanbul: İletişim.

Rifat, M. (2013). Açıklamalı Göstergebilim Sözlüğü: Kavramlar, Yöntemler, Kuramcılar, Okullar. İstanbul: Türkiye İş Bankası Kültür.

Schwartz, L. L. (1983). Family therapists and families of cult members. International Journal of Family Therapy. 5(3). 168-178.

Sperling, V. (2016). Putin's Macho personality cult. Communist and Post-Communist Studies, 49(1), 13-23.

Stanley, J. (2018). Demokrasilerde Propaganda Oyunu, Başak Karal (Çev.). İstanbul: The Kitap. 
Taylor, J. E. (2006). The production of the Chiang Kai-Shek personality cult, 1929-1975. The China Quarterly, 185, 96-110.

Tertitskiy, F. (2015). The ascension of the ordinary man: How the personality cult of Kim Ilsung was constructed (1945-1974). Acta Koreana, 18(1), 209-231.

Tumarkin, N. (1997). Lenin Lives! the Lenin Cult in Soviet Russia. USA: Harvard University.

Zorlu, Y., Çakı, C. \& Karaca, M. (2017). Türk Sinemasında Nazizm İdeolojisi: “Kırımlı” Filmi ve Göstergebilimsel Analizi. Sosyoloji Konferansları, (56), 67-95. 